\title{
An Analysis of Teachers' Beliefs toward Authentic Materials in Teaching Listening
}

\author{
Berlinda Mandasari \\ berlindamandasari22@gmail.com
}

STBA Teknokrat

\begin{abstract}
This research concerns on the study of analyzing teachers' beliefs toward authentic materials in teaching listening. This issue becomes important to analyze because teachers' beliefs containing conceptions, world views, and mental models about the materials will shape learning and teaching practices. The subject of this research was two English teachers who specifically teach listening skill by using authentic materials in Surakarta. The data were collected through observation, questionnaire and interview and were analyzed by using interactive model proposed by Miles and Huberman. The result of this research is teachers believe that : a) authentic materials are materials produced by a native speaker of the target language not for a teaching purpose, $b$ ) authentic materials must introduce English in the real context used by the native speaker, improve students' knowledge, Improve students' English competence in both spoken and written, improve students' vocabulary, introduce the culture of native speaker, improve students' listening ability, motivate students to learn, motivate students to learn autonomously, c) authentic materials are important to use since it is motivating students and providing some aspect of English that students can learn, $d$ ) authentic materials are considered to be carefully selected before being taught to the students, e) song attracts students' interest. The result implies that teachers' concept toward authentic materials has shape their belief.
\end{abstract}

Key Words: authentic materials, belief, teaching listening

\section{Introduction}

Teachers have something to do with the successful of students' learning English. Virtually all English teachers have certain preconceived ideas or beliefs about how the best approach in English teaching. They often come into an English classroom conditioned by their previous educational experiences, cultural backgrounds, and social interaction, which may further shape their beliefs about English teaching (Johnson, 1992a; Richards \& Lockhart, 1996; Smith, 1996). Khader (2012: 74) defines teachers' beliefs as a set of ideas rooted in these psychological and mental content of the teacher and play a central role in guiding his/her teaching behavior. In this context, beliefs are defined as conceptions, world views, and mental models that shape learning and teaching practices.

In relation to English teaching, teachers need to provide some teaching materials. Materials provide the content of the lesson, the balance of skills taught, and the language practice of the student. However, in many cases, listening skill is considered as difficult skill to learn by senior high school students. Some reasons beyond this statement are the students are not accoustomed to listen sounds in English produced by native speaker. They are provided with the material in the form of created materials that purposely produced to teach listening. By this condition, the students are not interested in the materials given by teachers. due to being uninterested, the students are not motivated in learning English. The other reason is that it is difficult for teachers to find listening materials. Created material is quite expensive to buy. Besides, it is also difficult to find the material unless the teachers create it by themselves. It takes time to create the materials since the making of materials need preparation. It is In line with the statement from Hedge (2000:237) who lists some problems which are internal to the listener such as lack of motivation towards the topic, negative reaction to the speaker or to the event; anxiety to rehearse one's own contribution to a debate or the next part of a conversation, to the extent of missing what the current speaker is saying; or distraction by the content of a talk into thinking about related topic thereby losing the thread of the argument.

Referring to the problem faced by students above, teachers solve the students' problem by introducing them with authentic materials which is basically designed not for teaching purposes. Thus, this research is conducted to identify teachers' beliefs toward authentic materials in teaching listening. 


\section{Theory and Method}

Qualitative case study is chosen as the design of this study. According to Merriam (1998: 19), a case study design is employed to gain in-depth understanding of the situation and meaning for those involved. The interest is in process rather than confirmation. It focuses on analyzing teachers' beliefs toward authentic materials in teaching listening. In this research, the researcher used theoretical sample of non-probability sampling in determining the sample of the research. Theoretical sample or purposive sample has purpose that person or case that is chosen can represent the answer of research questions (Setiyadi, 2006: 44). The participants in this research were two English teachers namely teacher Fr and teacher Sy. Teacher Fr is 36 years old. He has been teaching for 10 years. He just accomplished his master degree in 2014. Teacher Sy is 32 years old. He has been teaching for 6 years. He is still working for his thesis. Thus, by considering the purpose of this research, the subject of this research are the teachers that handle each class especially in the tenth grade to gain a more variative data. In conducting the research, the researcher follow some procedures as a guidance, they are: a) constructing instruments including questionnaire, note, and recorder, b) collecting data, c) analyzing data, d) reducing data, e) displaying data and f) verifying and concluding data. Besides giving questionnaire, the researcher recorded the teaching and learning process occured in the classroom which focus on how teachers handle the class. Data were collected through observation, questionnaire and interview and were analyzed by using Interactive Model proposed by Miles and Huberman (Miles and Huberman, 1984: 21-22).

Findings and Discussion

\begin{tabular}{|l|l|}
\hline \multicolumn{1}{|c|}{ Research questions } & \multicolumn{1}{|c|}{ Issues Arising } \\
\hline What are teachers' beliefs toward authentic & 1. Belief about definition of authentic \\
materials in teaching listening? & $\begin{array}{l}\text { 2. Reasons to use authentic materials } \\
\text { 3. The importance of authentic materials } \\
\text { 4. Criteria for selecting authentic materials }\end{array}$ \\
& $\begin{array}{l}\text { 5. Preference for particular authentic } \\
\text { materials }\end{array}$ \\
\hline
\end{tabular}

Table 1. The Summarized of Research Findings

\section{Teachers' Understanding about Authentic Materials}

Teacher Fr emphasizes authenticity toward the materials and focus that authentic materials are produced by native speaker of the target language. Teacher Sy relates authentic materials as the materials used by native speaker. Teacher Fr defines authentic materials which are summarized in the result of interview.

"Yang jelas authentic material itu materi-materi yang diambil dari berbagai sumber yang awalnya tidak untuk mengajar. Ngambilnya bisa dari internet. Pokoknya sifatnya otentik. Asli dari native speaker dan authentic material itu kan butuh extra menantang untuk mencarinya dan sifatnya lebih fresh tidak mudah ditebak ama murid." ["Any materials taken from many sources not for teaching purposes. It can be taken from internet in which it is authentic from the native speaker of target language. Authentic material is very challenging to obtain and it is fresh for students so that it is hard to predict". (Interview/Teacher Fr)]

In line with the statement given by teacher Fr, teacher Sy also states his definition about authentic materials.

"Materi yang dikembangkan oleh native speaker kalau disini kan bahasa inggris berarti kan asli origin dari yang ngomong. Setiap harinya ngomong pake bahasa inggris". ["the materials which are developed by native speaker. English is the target language used in authentic material in which it is spoken as daily conversation by the native speaker". (Interview/Teacher Sy)]

There are various definitions proposed by experts about authentic materials. No fixed definition is proposed. But the point is that authentic materials can be defined as any visual, audio or audio visual produced by native speaker not for teaching purposes. Generally, they believe that authentic materials are produced by native speaker of the target language not for teaching purposes. As it is supported by Gardner and Miller (1999: 101) who 
explained that authentic materials mean any text (printed or digital) or tape which was produced for a purpose other than teaching the target language. Knowing the teachers' understanding about the definition of authentic materials is in accordance to their beliefs toward the materials.

\section{Reasons to Use Authentic Materials}

Teacher Fr and teacher Sy have the same reasons in using authentic materials.

\begin{tabular}{|l|c|c|}
\hline \multicolumn{1}{|c|}{ Reasons to Use Authentic materials } & $\begin{array}{c}\text { Teacher } \\
\text { Fr }\end{array}$ & $\begin{array}{c}\text { Teacher } \\
\text { Sy }\end{array}$ \\
\hline Introduce students with language used by native speaker in real context & $\sqrt{ }$ & $\sqrt{ }$ \\
\hline Improve students' knowledge & $\sqrt{ }$ & $\sqrt{ }$ \\
\hline Improve students' English competence in both spoken and written & $\sqrt{ }$ & $\sqrt{ }$ \\
\hline Improve students' vocabulary & $\sqrt{ }$ & $\sqrt{ }$ \\
\hline Introduce the culture of the native speaker & $\sqrt{ }$ & $\sqrt{ }$ \\
\hline Improve students' listening ability & $\sqrt{ }$ & $\sqrt{ }$ \\
\hline Motivate students to learn & $\sqrt{ }$ & $\sqrt{ }$ \\
\hline Motivate students to learn autonomously & $\sqrt{ }$ & $\sqrt{ }$ \\
\hline Compulsory subject from the school & $\sqrt{ }$ & $\sqrt{ }$ \\
\hline$\ldots \ldots \ldots \ldots \ldots . . . . . . . .$. & & \\
\hline
\end{tabular}

Table 2. Reasons to Use Authentic Materials

Bacon and Finnemann (1990: 459-473) find that when students are properly prepared, authentic materials have positive effect on both comprehension and motivation. Lund (1990: 105-115) even recommends a trend toward bringing classroom-listening instruction and practice as close to real world listening as is possible. At this point, authentic materials are valuable resource in language teaching and in enhancing students' language comprehension.

\section{The Importance of Authentic Materials}

Teachers believe that authentic materials are important in teaching target language. The participants show positive attitude toward authentic materials. Teacher Fr believes that authentic materials are motivated in which teacher should bring something new in the classroom in order to motivate students. He explains:

"Yang jelas penting untuk menambah wawasan murid. Kalau saya cenderung tantangan itu tadi. Authentic material is fully motivated. Sangat memotivasi.Yang jelaskan kalau belajar bahasa kan belajar culture, belajar budaya. Ya kalau misalnya kita bisa memberikan sumber yang asli kenapa tidak. Masa percakapan contohnya di buku, percakapan bahasainggris kok namanya joko sama bandi. Joko sama bandi ya wagu mbak. Minimalnya kan kalo percakapan bahasa inggris kan george dan richard. Mosok percakapan bahasa inggris, joko, where are you? jadinya kan gak sesuai". ["Authentic material is clearly important to improve students' knowledge. I thought that authentic material is fully motivated. If we learn a language then we learn it's culture. It is possible for us to teach students by using authentic materials in which it is truly genuine. Doing conversation, for example, must use any names that indicate the real conversation between or among native speakers. How can the persons in doing conversation use the word Joko or Bandi? That sounds awkward. It must use George or Richard that indicate the names of native speaker. It sounds inappropriate to use local names". (Interview/teacher Fr)]

Otherwise, teacher Sy believes that authentic materials contain some aspects that students can learn from, including pronunciation and stressing. The result of the interview describes that authentic materials are very important. He said that:

"Ya penting banget. Anak-anak langsung belajar dari native itu. Pronunciation bagaimana,stressingnya ngomongnya bagaimana, banyak banget". ["It is very important. The students can directly learn from native speaker including how to pronounce the words, the way to stress the words and many others". (Interview/teacher Sy)] 
The main function of the second-language classroom should be to provide learners with authentic language (Ciccone, 1995: 203-215). Authentic language, in this case is English, should be given to the students by viewing the real language used by native speaker. Authentic materials are considered as materials that provide students with authentic language. Some reasons underlying the use of authentic materials are to exposure students with real language and cultural context embedded in the language.

Generally, the teachers believe that authentic materials are important to be used as a source to teach listening. It contains the genuine language used by native speaker of target language. Another important aspect of authentic materials are their significant impact on learners' motivation; with motivation defined here as the willingness to persevere in a learning task (Papalia. A, 1986: 23-24). Indeed, as both traditional and more current methods fail to involve the learner in the learning process, authentic materials are believed to enliven the classroom, being a powerful motivating factor, by providing motivation through enjoyment (Karpova, 1999: 18). By exposing to the real language, the teachers believe that students can be motivated in learning English and they would be exposure to the culture of who used the language. Giving as a material to teach listening, the teachers conclude that the students can easily catch the point of the audio-authentic material, in this case, song. They believe that the real language input can lead the students to learn English easily. As Shrum and Gilsan (2000: 133) say in which authentic materials provide an effective means for presenting real language, integrating culture and heightening comprehension.

\section{Criteria for Selecting Authentic Materials}

The data showed on the questionnaire and interview describe that the teachers have almost the same criteria in selecting authentic materials to teach listening. Criteria mean standards or any considerations that the teachers used in choosing authentic materials before being taught to the students. From the questionnaire, the teachers indicate some considerations that need to be involved in authentic materials.

\begin{tabular}{|l|c|c|}
\hline \multicolumn{1}{|c|}{ Criteria for Selecting Authentic Materials } & $\begin{array}{c}\text { Teacher } \\
\text { Fr }\end{array}$ & Teacher Sy \\
\hline The level of the students & $\sqrt{ }$ & $\sqrt{ }$ \\
\hline Students' needs & $\sqrt{ }$ & $\sqrt{ }$ \\
\hline The objectives of teaching & $\sqrt{ }$ & $\sqrt{ }$ \\
\hline Students' interest & $\sqrt{ }$ \\
\hline Students' age & $\sqrt{ }$ & \\
\hline Social value & $\sqrt{ }$ & $\sqrt{ }$ \\
\hline Moral value & & $\sqrt{ }$ \\
\hline Learning environment & $\sqrt{ }$ & $\sqrt{ }$ \\
\hline Classroom condition & $\sqrt{ }$ & $\sqrt{ }$ \\
\hline Students' character & $\sqrt{ }$ & $\sqrt{ }$ \\
\hline School culture & $\sqrt{ }$ & $\sqrt{ }$ \\
\hline The easiness to implement the materials & $\sqrt{ }$ & $\sqrt{ }$ \\
\hline Accessibility to the material & $\sqrt{ }$ & $\sqrt{ }$ \\
\hline The availability of the equipments &
\end{tabular}

Table 3. Criteria for Selecting Authentic Materials

Generally, teacher Fr and teacher Sy believe that any authentic materials should be able to provide something that students can learn from it. There are no best criteria in selecting authentic materials. However, the teachers have almost the same criteria for selecting authentic materials. As Laamri (2009: 16) pointed out that authentic materials should be:

1. Authenticity: The selected material should serve communicative goals.

2. Accessibility: The material should be easy for the learner to understand and suitable for the teacher.

3. Appropriateness: It should suit the learner's age, level needs and interest.

4. Applicability: It should suit the teaching context and makes the objectives attainable.

5. Adaptability: It should be adapted to the learners' level, needs and interests. 


\section{Preference for Particular Authentic Materials}

Teacher Fr prefers to use TV commercials, quiz shows, cartoon, news clips, movies, short story and novels, radio ads, songs, documentaries, slides, photographs, wordless street signs, pictures from magazines, wordless picture books, newspaper articles, movie advertisements, sport reports, lyric to songs, restaurant menus, street signs, tourist information brochures, maps and greeting cards. Teacher Sy uses cartoon, news clips, movies, short story and novels, songs, photographs, paintings, movie advertisements, sport reports, lyric to songs, maps and greeting cards. Interview is administered to ask teachers which materials that they preferred to use especially in teaching listening.

Teacher Fr believes that teaching by using authentic materials should cover the four English language skill; listening, speaking, reading and writing. He uses those selected materials in teaching English. The materials depend on what topic that students need to learn. He believes that any authentic materials should fit to the topic that students need to achieve. No particular authentic material is preferred. He emphasized it during being interviewed.

"Semuanya. Ada empat skill yang mencakup pembelajaran bahasa itu. Saya pakai semuanya. Enggak hanya video tok, lagu tok. Tergantung nemunya apa. Ya tentunya kan menyesuaikan dengan ini mbak, topiknya kita kan mau membahas tentang description atau descriptive text otomatis nyari teks yang sifatnya descriptive. Kalo pas misalnya kelas XII ketemu dengan materi discussion, nyarinya lagu yang discussion, kayak father and son". ["I use all, depending on what I find. When I am going to teach descriptive text, then I look for the text in the form of descriptive. Teaching in the twelve grades, for example, I use song entitled Father and Son to teach discussion text". (Interview/teacher Fr)]

On the other hand, teacher Sy prefers song to teach listening to the students. He believes that students pay more attention to songs compared to others. Beside that, he believes that songs did not take time in the teaching process compared to movie.

"Song. Karena apa ya lebih enak dan lebih anak-anak itu lebih suka cenderung intes banget ke lagu daripada percakapan atau kalau movie ya bagus tapi kan kepanjangan. Waktunya nanti gak keburu. Iya. Kalo kan cuma untuk tarolah satu lag kan nanti bisa dikembangkan jadi dua jam. Langsung hasilnya kan jadi. Kalau film kan butuh beberapa pertemuan". ["I prefer songs because the students prefer to study through songs to other materials. Movie is one of the preferable but it takes time because it can not be taught in one meeting". (Interview/teacher Sy)]

At this point, the findings show that teacher Fr points out that no particular authentic materials are preferred. It is just because teaching English at school should be integrated to four skills of English. The selection of materials depends on what objectives that the students need to achieve. However, students are likely to enjoy the class when they are taught by using songs. Meanwhile, teacher Sy believe that song is preferable because students are more interested in learning English through songs. He also believes that teaching by using songs does not take time. Eken (1996) stated that songs can be utilized in foreign language teaching for many purposes. According to him, songs can be used:

1. To present a topic, a language point, lexis, etc.

2. To practice a language point, lexis, etc.

3. To focus on common learner errors in more direct way.

4. To encourage extensive and intensive listening.

5. To stimulate discussion of attitudes and feelings.

6. To encourage creativity and use of imagination.

7. To provide a relaxed classroom atmosphere.

8. To bring variety and fun to learning.

\section{Conclusion}

Belief has something to do with teaching practice. Since belief comes from the mind concept of teachers, teaching practice is the real act of beliefs. Thus, knowing teachers' beliefs become very important to help teachers improve their teaching process and teaching performance to bridge the students to achieve their goals. Specifically, this research can be concluded that teachers believe that: 
1. Authentic materials are materials produced by a native speaker of the target language not for a teaching purpose.

2. Authentic materials can introduce English to the students in the real context used by native speaker, improve students' knowledge, Improve students' English competence in both spoken and written, improve students' vocabulary, introduce the culture of native speaker, improve students' listening ability, motivate students to learn, motivate students to learn autonomously and it is compulsary subject from the school.

3. Authentic materials are important to use since it is motivating students and providing some aspects of English that students can learn from, including pronunciation and stressing of words.

4. There must be some considerations in selecting authentic materials. Tacher Fr considered the objectives of the lesson when selecting it and the material should meet the core competence representing spiritual attitude, social attitude, cognitive aspect and skill respectively required by curriculum. On the other hand, teacher Sy considered students' level, the purpose of teaching, students' interest, social value, moral value, easy access to the materials and the availability of the equipments as criteria for selecting authentic materials. Thus, They believe that authentic materials are considered to be carefully selected before being taught to the students.

5. Song attracts students' interest.

\section{References}

Bacon, S. M., \& Finnemann, M. F. (1990). A Study of the Attitudes, Motives, and Strategies of University Foreign Language Students and their Disposition to Authentic Oral and Written Input. The Modern Language Journal, 74, 459-473.

Ciccone, A. A. (1995). Teaching with authentic video: Theory and practice. In F. R. Eckman, D. Highland, P. W. Lee, J. Mileham, \& R. R. Weber (Eds.), Second language acquisition theory and pedagogyMahwah, NJ: Erlbaum, 203-215.

Gardner,D \& Miller. (1999). Establishing Self Access. Cambridge: University Press.

Hedge, T. (2000). Teaching and Learning in the Language Classroom. Oxford: Oxford University Press.

Khader, Fakhri R. (2012). Teachers' Pedagogical Beliefs and Actual Classroom Practice in Social Studies Instruction. American International Journal of Contemporary Research, 2(1).

Khaniya, T. R. (2006). Use of Authentic Materials in EFL Classrooms. Journal of NELTA, 11(2), 17- 23.

Kienbaum, B. E., Barrow, G. R., Russell, A. J., \& Welty, S. (1986). Communicative Competence in Foreign Language Learning with Authentic Materials. Final Project Report.

Krashen S. (2008). Language Education: Past, Present, and Future. Regional Language Centre Journal, 39(2), 178187.

Kukari, A, J. (2004). Cultural and Religious Experiences: Do They Define Teaching and Learning for PreService Teachers Prior to Teacher Education? Asia-Pacific Journal of Teacher Education, 32(2), 95110.

Lund, R. J. (1990). A Taxonomy for Teaching Second Language Listening. Foreign Language Annals, 23, 105115.

Maher Salah, Sh. (2008). The Relationship between Vocabulary Knowledge and Reading Comprehension of Authentic Arabic Texts. Unpublished MA thesis. Brigham Young University.

Macdonald, M., Badger, R., \& White, G. (2000). The Real Thing? Authenticity and Academic Listening. English for Specific Purposes, 19, 253-267.

MacDonald, M. N. \& Badger, R. Dasli, M. (2006). Authenticity, Culture and Language Learning. Language and Intercultural Communication, 6(3\&4), 250-260.

McDonough, J. \& Shaw, CH. (2003). Materials and Methods in ELT. London: Blackwell Publishing.

Martinez, A. (2002). Authentic materials: An overview. Karen's Linguistic Issues. Retrieved October 29, 2014 from http://www3.telus.net/linguisticsissues/ authenticmaterials.html. 
Melvin, B.S. and Stout, D.S. (1987). Motivating language learners through authentic materials. In W. Rivers (ed.) Interactive Language Teaching. New York: Cambridge University Press, 44-56.

Merriam, Sharan B. (1998). Qualitative Research and Case Study Applications in Education. San Fransisco: Jossey-Bass Publisher.

Miles, Matthew B. \& Hubberman, A. Michael. (1984). Qualitative Data Analysis: A Source Book of New Methods. California: Sage Publication.

Miller, L. (2003). Developing Listening Skills with Authentic Materials in the Language Classroom. Oxford: Oxford University Press.

Mishan, F. (2005). Designing Authenticity into Language Learning Materials. Bristol: Intelect Ltd.

Morrison, B. (1989). Using News broadcasts for Authentic Listening Comprehension. ELT Journal, 43, 14-18.

Nespar, J. (1987). The Role of Beliefs in the Practice of Teaching. Journal of Curriculum Studies, 19, 317-328.

Nunan, D. (1998). Language Teaching Methodology. London: Prentice Hall.

Nunan, D. (1989). Designing Tasks for the Communication Classroom. Cambridge: Language Teaching Library.

Miles, Matthew B. \& Hubberman, A. Michael. (1984). Qualitative Data Analysis: A Source Book of New Methods. California: Sage Publication.

Setiyadi, B. (2006). Metode Penelitian untuk Pengajaran Bahasa Asing Pendekatan Kualitatif dan Kuantitatif. Yogyakarta: Penerbit Graha Ilmu. 